hope that an intcresting man who lived in a most interesting period may yet find a biographer who will adequately bring him into the light out of the shadow of the giants who were in the earth in those days... Cromwell, Milton, Newton, Spinoza, Boyle-in the midst of whom he moved, and by whose great names his own has hitherto been too much obscured.

HFRBERT RIX.

\section{THE NATURAL HISTORY OF EAST EQUATORIAL AFRICA.}

$\mathrm{E}$ geology of East Equatorial Africa has been recorded in a very general way in the maps of the region published by Mr. Jos. Thomson in his "Through Masai Land," and in the more recent one of Prof. Toula ; from these it was known that the area consists of a basal plateau of gneiss and schists, covered by a series of lavas in the interior and marked along the coast by patches of Jurassic rocks. My work therefore lay in the main in the examination of the gneisses and schists with a view to the determination of the method of their formation; also to the study of the volcanic rocks - which range from basalts to quartz trachytes--and of the relations of the old lava plateaus and sheets to the craters of various ages which play such a striking part in the scenery of the district. The most interesting part of the work consisted in the examination of the great "Graben" or valley of subsidence which runs north and south across the district; on the floor and on the sides of this are many old lake deposits now buried by lava flows, while the walls are also marked by terraces formed by the existing lakes when at a higher level than at present, or by old ones that have long since disappeared. In some of these terraces are shells with Nilotic affinities, though the localities are now far from the Nile basin. The collections made from the coast Jurassics will allow the age of these beds to be definitely settled, and the fossils--Ammoniles, Lwtoceras, belemites, Sc.--suggest that they are probably Callovian. An interesting addition to the geology of tropical Africa has been the discovery of some lalaonoic shales, more than 130 miles from Mombasa, which have yielded a fairly good fauna, though richer in individuals than species.

The evidence collected proves the existence of a former race of men who used obsidian implements, and who lived in a period long prior to any existing tribes; and also, that the glaciers on Mount Kenia once extended several thousand feet further down the mountain than at present; in fact, a regular sheet or cap glaciation preceded the existing valley glaciation.

Zoologically the district is somewhat barren, and in many parts only animals with great powers of migration or hybernation are to be seen. In some of the country most famous for its game, none can be found, as it was killed off by last year's drought Cattle disease is responsible for the disappearance of many species; thus, whereas buffalo used to be extremely common, only three were seen; only one herd of giraffes was met with. 7ebra and ostriches are abundant in places, while the commonest antelopes seen were the hartebeest, mpalla, and water buck: topi are numerous on the Tana. The sparseness of dense forest, except on the higher parts of the district, accounts for the rarity of monkeys. Colobus guerazi was seen at ovcr 9000 feet on Kenia, and some baboons amid the rocks of one of the ridges of the basin of Lake Kibibi. Hyena and a small bush buck range up into the lower Alpine zones on Kenia, while a small rat, Hyrax, and elephants occur in the woods of Senecio jolntistoni in the upper Alpine zone. Another high record is the occurrence of fresh water crabs (Telcphusa) in some swamps on Leikipia at the height of about 8000 feet.

The rarity of limestones doubtless helps to the scarce- ness of mollusca. As is well known, most of the species live on trees, whether in river valleys, such as the Sabaki, or among the forests of Kenia, where some small delicate species are common from 8000 to 10,000 feet.

Botanically also, the country is somewhat barren and monotonous; vast areas are covered by nothing but low, umbrella-shaped acacias. The country may be roughly divided into seven zones. The first includes the coastal plain and river valleys, characterised by the abundance of palms, such as the Dum palm (Hyphanc thebaica) and the Borassus palm (B. Alabelliformis); the former is abundant along the coast and fringes the rivers, being found up the Tana as far as south of Kenia, and up the Sabaki to Tzavo. The Screw palm (Pandanus) is rarer, but has a similar range. The salt marshes and lagoons are bordered by the mangrove, while the she-oak, or Casuarina, occurs on the ends of exposed promontories on the coast. These have doubtless grown from cones carried by currents from Australia, just as the Krakataio pumice, which now forms banks along the shore, has floated from Malaysia. This zone is succeeded by great sandy steppes covered with mimosa and acacia scrub, with large baobabs, which occur also on the coast. 'The most typical plants have large and white flowers, a species of Convolizulus being the commonest. Aloes, and especially the species known to the Suahili as "nkonge," are abundant. The two next zones are the steppes and woods of the high plateaus; the most striking feature of the former is the high grass, which, when the seeds are ripe and yellow, reminds one of the great cornfields of Dakota.

In places the forests of the plateaus pass upward gradually into those of the flanks of the higher mountains, such as Kenia and Settima. The prevalence of lofty junipers which replace the trees of lower horizons, and the dense jungles of bamboos, with a carpet of selaginclla characterise the fifth or bamboo zone.

Above this are the Alpine pasturages. In the lower part there are numerous orchids, Gladiolus, \&c. With the upper zone there appear species of the "everlasting plants" of the Cape, while the only trees are Senecio jolnstoni. Beyond this is the zone above the snow line, where except for a few diminutive yellow composites and lichens, we have passed beyond the realms of plant or animal life.

J. W. GREGORY.

\section{NOTES.}

Dr. Potalx has been elected a member of the Paris Academy of Sciences (Section of Medicine and Surgery), in the place of the late Prof. Charcot.

W'E are sorry to learn of the death of Dr. H. H. Ashdown, on October ro, at the age of thirty-four. He was a Fellow of the Royal Society of Edinburgh, and published several memoirs on his phy'siological investigations.

WE regret to announce that Mr. T. C. Bain, the Government surveyor and geologist at the Cape, died at Rondebosch, Cape Town, on September 28. He was born in 1830 , and his father was the engineer of the well-known Mitchell's Yass Road, at Cape Colony. Mr. Bain was appointed irrigation and geological surveyor in 1888 . The British (Natural History) and Cape Museums contain a number of geological specimens collected by him, among which may be mentioned the collection of reptilian remains from the lacustrine beds of the Karoo.

A STate. Museum is now in course of formation at Pretoria. Mr. P. Krantz has been appointed a curator, and he has, with an entomological assistant, just started on a collecting expedi. tion, which may probably occupy a space of two years. Their mode of transit is in a large wagon drawn by twenty donkeys, these animals having been chosen as best able to withstand the

NO. I 253 . VOL. 49] 
vicissitudes of climate and attacks of "fly" pertaining to some parts of the country proposed to be visited. This wagon has been stted inside and outside with shelves and other paraphernalia for bolding specimens, cork, medicaments, \&c. When not travelling, accommodation is found in a large marquee fixed to the side of the wagon, from which step-ladders, dissectingtables, \&.c., may be let down. $A$ lighter and rougher wagon, suited to more inaccessible country, also accompanies the party. Everything has been done to favour the success of this expedition, and the Raad has passed a resolution speciaily exempting those engaged in it from the provisions of the game law. The nucleus of a good general collection should thus surely be obtained, whilst the idea of collecting the 'Transvaal fauna is highly to be commended.

Ax appeal for subscriptions to found a Pasteur Institute for India is about to be made (says the Allahabad Pioncer). It is proposed to locate the institution in some convenient place near Simla. There the necessary laboratories, fitted with the best scientific appliances, quarters for the officials, and accommo. dation for patients will be provided. The expenses will be very considerable, but the Government of India, besides giving their cordial approval to the scheme, have contributed notable help by promising the services of a selected medical officer. India bas bitherto taken very little interest in bacteriological work, though almost every European nation, America, ancl Japan are devoting a large amount of attention to it. It is hoped that in addition to its anti-rabic work, the Indian institute may be put on such a footing as to enable it to carry on original research in this and other directions. The institute should also serve as a tra ining school in practical bacteriology for medical men in India. The scheme is full of promise, and there should be little difficulty in obtaining the funds necessary to carry it out.

Ar the Institution of Electrical Engineers, on Thursday, November 9, Prof. George Forbes, F.R.S., will read a paper on "The Electrical Distribution of Power."

Acconding to the Pretoria Press, and from a Blantyre source, a very large supply of ivory has come down from the Lake, in the Lake Company's possession. Huge 6 feet and cven 7 feet tusks were to be seen at Mandala, and several thousand pounds must have been paid the Arab; in exchange for this valuable commodity.

Ax International Horticultural Society was founded at the recent congress of horticulturists held at Chicago. The chief object of the society is to facilitate the exchange of plants, seeds, books, \&c. The following officers have been nominated:President, P. J. Berchmans; Vice-President, Henry I. de Vil. morin; Secretary and Treasurer, Mr. George Nicholson, the Curator of Kew Gardens. We are informed, however, that Mr. Nicholson is unable to undertake the work that this office would impose upon him.

AN International Exhibition of Industry, Science, and Art aill be opened at Ilobart, Tasmania, on November, 1894 , and will continue open for a period of about six months. The exhibits will be arranged into twenty-four classes. Clasi $\mathrm{X}$. is Chemistry, Apparatus and Processes, Philosophical Instruments; XI. is devoted to Electricity; Gas and Lighting, other than Electricity, is the subject of Class XII. The following classes are also of scientific interest : XVI.-Machinery, Machine Tools, Iydraulic Machines, and Machines for raisin: heavy weights, Elements of Machines, Furnaces; XVII.-Prime Movers, and means of distributing their power, Railway plant; XVIII.Naval Architecture and Engineering; $X I X$.-Civil Engineering, Construction, and Architecture, Sanitary Appliances, Aeronau. tics, Sc. ; XX.-Mining and Metallurgy, Minerals, Quarrying, and Fuel; XXI.-Agriculture, Iorticulture, Arboriculture; XXII.-Fisheries.

A corresponinfit writes: "There seems still little recorded as to the maximum or average size of the flying fish, Lixucotus sp. On my voyage to the Cape, on board the R.M.S. Drummond Castle, in about the longitude of (ireenwich and the latitude $\mathrm{I}^{\circ} \mathrm{S}$, ard on September 9 last, a specimen Hew, or was blown, on board, where the bulwarks were 19 fect to 20 feet above the water, which measured $1 S: 3$ inches long, with an expanse of $22 \frac{1}{2}$ inches across the wings. This was the largest specimen that has ever passed through my hands. It only weighed I lb. $6 \mathrm{oz}$, but a development in weight wouk clearly be disadvantageous to its power of flight."

Is the notice of Prof. Sylvester's life which appeared in NATURE for January ISS9 (vol. xxxix. p. 217), it is mentioned that after coming out at Cambridge as Second Wrangler, "he was incapacitated by the fact of his Jewish origin from taking his degree," and it is added that in "more enlightened times ( $1 S_{72}$ ) he had the degrees of B.A. and M. A. by accumulation conferred upon him." The learned librarian of Trinity College, Dublin, Rev. Dr. Abbott, calls our attention to the fact, which should not be overlooked, that though unable to take the degree at Cambridge, he actually passed a.t cundem to Dululin University, and had the degrees of M.A. and M.A. conferred $u_{p}$ on him there (in virtue of his Cambridge qualification) in $\mathrm{r} 8_{4} \mathrm{I}$. The honorary degree of LL. D. was also conferred upon hin by Dublin in $\mathbf{1 8 6 5}$. It may not be without interest to mention that the first Jew to obtain a degree in the Linited Kingdom was Nathan Lazarus Benmohel, who graduated B.A. at Dublin in 1836 , and M.A. in 1846 .

Six years ago Hofrath Dr. A. B. Meyer, Director of the Natural History Museum at Dresden, published in the Abhand. lungen unt berichte des $K$. Zool. Museum Zu Dresden, a series of descriptions and drawings of iron-framed cases, and of other museum fittings and apparatus introduced by him in Iresden. Since then a good deal of attention has been directed to the subject of metal instead of wooten framing in museum cases; and in $18_{91}$ Dr. Meyer gave further details as to his experience in a communication to the Museums Association meeting at Cambridge. In the Abhandlungen of the Dresden Museum for the year $1892-3$, just published, Dr. Meyer returns to the subject of iron-framed cases, on the details of which his recent experience has suggested several improvements. In a series of twenty li:hographic and photographic plates, accompanied by elaborate specifications, measurements, Sc., lie deals with several forms of case, with store cabinets and their fittings, with trays for eggs and nests, sheet iron trays for shells, supports for skeletons and crania, craniometers, and several other varieties of museum appliance and case fitting; In truth Dr. Meyer has, with real German patience and industry, drawn and described in an exhaustive manner a range of museum cases and appliances which every curator more or less works out for himself, and of which, having by rule-of-thumb or otherwise attained his object, he thinks no more. But, as Dr. lyeyer points out, museum officials are much given to experimenting at a lois of both time and money, and there is no reason why the results of wcll-matured experience should not be authoritatively laid down and generally accepted as a basis from which to reach forward to further improvements. The only other means than publication by which museum officials can obtain the results of mutual experiments and experiences is by visits to museums, but by that means alone the observer cannot get the precision of information and the working details which are conveyed by Dr. Meyer's monograph. The publication indeed confers a signal benefit on all interested in museum work, and it is much to be destred that

No. 1253 , voL. 49] 
others having like valuable experience should follow Dr. Meyer's example, and put down with precision what they know and have accomplished for the benefit of the ordinary museum officer.

Dr. Karl Dove, in a letter addressed to the President of the Berlin Gesellschaft für Erdkunde, gives some interesting particulars regarding the climate and vegetation of South Damaraland. The numerous larger rivers, or rather watercourses, of the country contain water almost throughout the year, which in the dry season, however, is found underneath the superficial layer of sant. In A ugust of last year Dr. Dove even found a strongly flowing brook, about ten feet broad, in the hot and dry valley of the lower Swakop. He attributes the permanence of the rivers to the profusion of strong inclines and the scarcity of purely horizontal plains, which has the effect of diminishing evaporation. The great efficiency of the protection afforded by the soil even in that dry country is shown by the fact that in places where moisture could only be due to rain, traces of it were found in samples at the depth of three feet after five months of the dry season. The amount of atmospheric precipitation was abrormally large during the last rainy season, and the sky was clouded very much like a north European rainy sky. During January over I I 8 inches were recorded in the vicinity of the higher mountains of IVindhoek and the Sheep River. At Windhoek itself the mean rainfall is estimated at 15.8 inches. The discovery that the rainfall does not show a further increase from lat. S. $22^{\circ}$ to $19^{\circ}$ is of special importance.

A $\mathrm{T}$ a recent meeting of the British Ornithologists' Club, the Hon. Walter Rothschild read some notes on the genus Apteryx, and exhibited a very extraordinary number of living specimen; of these "wingless" birds of New Zealand. He recognises the following as a complete list of the species at present known :$A$. australis, Shaw, from the South Island ; $A$. lazeryi, ${ }^{*}$ sp. nov. from Stewart Island; A. mantelti,* Bartl. from North Island; $A$. ozveni,* Gould, the east coast, South Island; $A$. oiveni occidentalis, * sub-sp. n., the North Island, and west coast, South Island ; $A$. haast $i$, Potts, central South Island and west of the North Island ; and $A$. maximus, Verr. (sp. dub.), South Island. Males and females of those marked with an asterisk were exhibited, and also a female specimen of the new sub-species. Mr. Rothschild is engaged on a monograph of these strange birds.

DURING the construction of the Puy-de-Dome Observatory in 1872 , the ruins of a large temple were discovered (says $M$. Plumandon in La Nature). From a tablet bearing a wellpreserved inscription it appeared that the temple was consecrated to Mercury, and, according to historians, it was destroyed towards the end of the third century. Near the middle of the ruins of the temple, in the part that was originally the most highly decorated, there stands a small vertical wall, about one and a half yards high and rather more than two yards long, built of rectangular blocks of stone four inches high and about six inches in length. The blocks are of two different colours, one kind being of light dolomite, while the other is a black lava. The two colours are alternated in each horizontal row, and the rows are arranged so that the vertical joint between any two blocks falls at the middle points of the blocks above and below it. Proceeding, therefore, from the bottom to the top of the wall, or vice versa, the faces of the blocks of each colour form a zigzag pattern of which the lines are inclined about $60^{\circ}$ to the horizontal lines separating the successive layers of stone. In fact, the mosaic constitutes a system of parallel lines cut by oblique lines of precisely the same kind as that which is frequently figured in illustration of optical illusions. When the wall is viewed from a short distance the horizontal layers seem to lose their parallelism, and appear to converge towards the interior of the angles formed by two consecutive series of obliques. Zöllner first culled attention to NO. 1253 , VOL. 49] the apparent loss of parallelism which truly parallel lines undergo when they are cut by oblique lines, but it is possible that the mosaic was designedly constructed to deceive the eye, and played an important part in the ceremonial of the temple on the Puy-de-Dome one thousand seven hundred years ago. Nitil novum sub sole.

MR. E. A. ANDREws describes in the last (October) number of the Studies from the Biological Laboratory of the Folnns Hoplins University an undescribed Acraniate, Asymmetron lucay. anum, found in considerable numbers between North and South Bemini, Bahamas, in June and July 1892 . They were taken in the tow-net while swimming at or near the surface, most abundantly at the early part of the ebb-tide when it had been high tide about nine o'clock in the evening, rarely in the daytime, or late at night, or on the rising tide. They were also obtained buried in the sand flats, but not very abundantly. The specimens taken in June were larger, often sexually mature, while those taken later were generally immature or larval forms. In captivity their habits were like the European lancelet, the largest was $16 \mathrm{~mm}$. in length and sufficiently translucent to enable one to trace the food or carmine granules to be traced through most of the digestive tracts. The peculiarities of this form, and those which induced the author to venture to refer it to a new genus, are briefly: the gonads being present only on the right, instead of on both sides as in Branchiostoma, the ventral fin having no fin rays, and there being a long caudal process.

A PAPER was read lately by Mr. H. B. Stocks to the Edinburgh Royal Society (Proc. Roy. Soc. Edin. p. 7o), "On Certain Concretions from the Lower Coal Measures, and the Fossil Plants which they contain." The interest which attaches to these concretions, or "coal-balls," is the remarkably perfect state of preservation of the fossil contents, in many cases fine plant-cells and fibres being preserved even without complete petrifaction. Chemically analysed, the petrified wood yields mainly carbonate of lime and iron pyrites, each in the proportion of 48 per cent. The late Mr. Binney suggested that the carbonate of lime was dissolved from shells in the marine strata overlying the concretionary beds and re deposited on the plants, but, as $\mathrm{Mr}$. Stocks points out, this assumes the lapse of a considerable period of time between the beginning of vegetable decay and the process of petrifaction, a period which would be under ordinary conditions fatal to the preservation of the delicate vegetable tissues. Mr. Stocks thinks that decay and petrifaction went on simultaneously, and hopes to prove the following explanation o the mode of petrifaction : by the process of osmosis water cun taining the usual quantity of carbon sulphate in solution, passes through the vegetable tissues of the plant, and sets up a series of chemical changes resulting in the formation of carbonate of lime and iron pyrites. The sulphuretted hydrogen combines then with more iron. The spheroidal shape of the nodules is, he believes, merely due to the deposition of calcium carbonate from a solution heavily charged with organic matter.

THE October number of the Annals of Scotish Natural His. tory contains several interesting articles, amongst them being one by Mr. Peter Adair, on the disappearance of the shorttailed field vole (Arvicola agrestis), and on some of the effects of the vole plague. This destructive rodent began to be observed in the infested area a few years before 1890 ; it multiplied with rapidity until the summer of 1892 , when the numbers began to decrease, and by the summer of the present year the pest had disappeared. Mr. Adair finds that the disappearance has been general over the whole infested area. On some farms the normal numbers remain, but on others scarcely a vole is to be seen. Various causes have been suggested to account for the disappearance. The drought of last spring and winter may have had some good effect, for the animal is partial to damp 
ground. There is, on the other hand, evidence that an epidemic caused the plague to come to an end. But it is the general opinion of the farmers and shepherds of the district from which Mr. Adair obtained his particulars, that the disappearance is due in a great measure to the work of such natural enemies as the owl, kestrel, rook, blackhead gull, and buzzard, the stoat, and the weasel.

THE Weather Bureau of Washington has published an elaborate discussion of the climate of Chicago, by Prof. H. A. Hazen, being No. 10 of the valuable Bulletins now being issued by that department. The city of Chicago is situated at the south-west of Lake Michigan, whose elevation is about 580 feet above the level of the sea. The earliest observations available were made in 1832 , and continued until 1836 , after which time they were of a very fragmentary character until November, 1859 , since which a continuous series of observations has been maintained, at least as far as regards the temperature. The lake has naturally great influence upon the climate, and this has been investigated in great detail for each separate element. With regard to the winds, the tables show that for the year there is a maximum from the south-west, and a secondary maximum from the north-east. During the cold months there is a marked preponderance of land winds, while in the warm months there is a slight preponderance of lake winds. The mean temperature deduced from twenty years' observations is $48^{\circ} \cdot 6$, and occurs about the third week in April and October. The highest temperature occurs about the middle of July, and the lowest the third week in January; for I 74 days the temperature is rising, and during $\mathbf{I} 9 \mathrm{I}$ it is falling. The cold spell about the middle of May, which is generally observed in the northern hemisphere, is well marked in the 5 - day means. The highest temperature observed was $99^{\circ} .6$ on July 17,1987 , and the lowest $-23^{\circ}$ on December 24, I872. The maximum temparature was $90^{\circ}$ or over on I2I days during 20 years, and a minimum temperature of $-15^{\circ}$ or below was only reached 16 times. Accurate rainfall observations can scarcely be said to begin at Chicago before 1867 . The annual rainfall from this series is 34.4 inches, and is fairly well spread over each month. $A$ fall of 2.5 inches in a day only occurred 15 times in 20 years. The work contains an abstract of the observers' Journal since the occupation of the station by the Weather Service, which includes an interesting account of their experience of the great fire of October 8-9, $187 \mathrm{I}$.

WE learn from the report on the administration of the Meteorological Department of the Government of India that the valuable series of meteorological observations which were taken by the late Mr. J. Allan Broun at Trevandrum during the years 1853-64 are being prepared for publication by that department, owing to the action taken by the Royal Societies of London and Edinburgh, and by the Meteorological Council with that view. It is proposed to publish them in three volumes containing (I) hourly observations, (2) comparative observations at various stations on the iTravancore Hills, and (3) discussion of the observations. The report shows great activity in the collection of observations from ships entering the Hooghly; these observations are used in the construction of daily charts of the Indian land and sea area, the publication of which began with January this year. The growing usefulness of ordinary weather forecasts is exemplified by the fact that they have been extended to expeditions in the field, and they have been pronounced by the military authorities to have been very successful.

Herr P. C'ZERMAK publishes, in Wiedemann's Annalen, some beautiful photographs of ascending currents in gases and liquids. For the former a box of rectangular section was used, consisting of plate-glass sides firmly cemented together. At the centre of the bottom was placed a flat spiral, the escape spring of a large spindle clock. The spiral could be heated by the passage of an electric current. A glass tube opened into the box at the bottom, directed towards the centre, for the introduction of smoke. A second glass tube led in at the top, for ventilation or the introduction of a light gas. Tobacco smoke blown in through the lower tube was seen to spread out on the bottom in a uniform layer, provided all parts of the box were at the same temperature. The touch of the hand on one side was sufficient to produce an ascending current and a motion of the smoke towards the warmer side. It was therefore necessary to perform the experiments in a room kept at a uniform temperature. On sending a current through the spiral, the mushroom-like figure first described by Vettin was observed to rise in faultless sym. metry. This was photographed by flash-light, and the reproductions show the spiral convolutions to great perfection. Since the contours reflected the greatest amount of light, they stand out well from the dark background, and clearly exhibit the interior structure of the stream-figure. In order to imitate more closely the actual condition of the atmosphere during the ascent of warm air currents, the upper part of the box was filled with coal-gas. The stream-figure then ascended in the usual manner until its vertex reached the lighter stratum. It then became stationary, expanded in the diffusion stratum, and part of the smoke trickled back to the bottom. Sometimes it was found possible to obtain a cloud-like structure, with a dome in the centre and wavy outlines. The figures were more easily produced and photographed in the case of liquids, but the general type remained the same.

INVESTIGATIONS are carried on at the Agricultural Experiment Station, Purdue University, Indiana, on much the same lines as at Rothamsted. Bulletin 45 of the Station contains in formation of interest and importance concerning wheat-growing in Indiana. From field experiments extending over ten years it appears that none of the varieties of wheat tried have any tendency to deteriorate or "run out," provided proper care is exercised. No wheat proved to be "rust-proof," but early wheats were generally less injured by rust than later kinds. Eight pecks of seed per acre gave the best returns at the Station, the average yield for nine years being $30^{\circ} 35$ bushels per acre. The best results came fron sowing; made not later than Septe nber 20 . The value of crop rotation in maintaining yields of grain has been strongly emphasised, for a comparison of rotating crops with constant grain cropping for seven years showed an average gain of 5.7 bushels per acre in favour of the former. Another important result obtained was that wheat may be harvested at any time from the dough stage to the dead-ripe condition, without appreciably affecting the weight or yield of the grain. Finally, a comparison of form; of nitrogen as fertilisers for wheat indicated that sulphate of ammonia is better than nitrate oi soda or dried blood.

IN a former note (June 22,1893 ) we have given a sho $r$ account of the means employed by Signor Augusto Righi to obtain electro-magnetic waves of small wave-lengths (about $8 \mathrm{~cm}$.), and also on p. 299 , vol. xlviii. we have described some of the experiments he has performed, using waves of this small wave-length. Since then Righi has continued his researches, and has published in the Proceedings of the Royal Academy of Lincei an account of his experiments on the question as to whether the electric force is perpendicular to, or in the plane of polarisation. Trouton, from his experiments on the reflection of electro-magnetic waves from the surface of non-conductors, such as glass and paraffin, has come to the conclusion that the electric force is perpendicular to the plane of polarisation. The reflection of these waves from paraffin, and also from metals, has been studied by Righi, who finds a marked difference in the two cases. In the

$$
\text { NO. I } 253 \text {, VOL. 49] }
$$


case of paraffin his results agree with those obtained by Trouton; when, however, a metal is used as the reflector he finds that the plane of polarisation is parallel to the electric force. The author has measured the refractive index, for oscillations having a wave length of $7.5 \mathrm{~cm}$. of the paraffin used in his experiments. He employed for this purpose an equilateral prism, each face being $20 \mathrm{~cm}$. high and $37 \mathrm{~cm}$. broad, and found $\mathrm{I}_{4} 4$ for the refractive index. The paraffin employed was not of the highest quality, although it was quite white and homogeneous, and had a melting point of $50^{\circ} \cdot 5 \mathrm{C}$.

Dr. OETTEL has continued his researches on the phenomena of the electrolytic deposition of metals (see NATURE, July 6, I 893). In the present paper, which is published in the Chemiker Zitung, he gives the results he has obtained in his investigation of the condition of an auxiliary electrode placed between the two principal electrodes in a copper voltameter. For an auxiliary electrode 86 by $131 \mathrm{~mm}$. in size, being a little smaller than the principal electrodes, he finds that copper is deposited on the side next the anode, and dissolved at the side next the cathode; the quantity dissolved being larger than the quantity deposited in nearly the same proportion as at the principal electrodes. This difference is caused by the electrodes not being composed of pure copper. The deposit on the allxiliary electrode attains as much as 87 par cent. of the deposit on the cathode; but depends on the following conditions:-(1) The relative dimensions of the auxiliary electrode and of the chief electrodes. (2) The absolute size of the electrodes; for, since the copper tends' to be deposited chiefly at the edges, the proportion increases when the plates are small.

IN order to ascertain if rifle bullets are capable of carrying infection, Messner (Mïnchener metl. Wochenschrijt, 1892, No. 23) has been making careful experiments with bullets purposely infected with particular micro-organisms. Bullets thus treated were discharged into tin boxes at a distance of from 225 to 250 metres. These boxes were filled with sterile gelatine peptone, and the channel in the latter made by the passage of the bullet was carefully watched and examined. It was found that in all cases the infected bullets had produced growths of those organisms in the gelatine with which they had originally been brought in contact. In some experiments the boxes, whilst filled with sterile gelatine, were covered over with flannel previously infected with particular bacteria, so that before reaching the gelatine the bullet would first have to pass through the former. Ordinary uninfected bullets were used, but in every instance bacterial growths made their appearance in the subjacent gelatine corresponding to the particular organisms present on the flannel. On the other hand, ordinary bullets, when discharged direct into the gelatine, occasioned only the appearance of moulds and other bacteria usually found in the air. Thus the heat communicated to the bullet during its discharge is not sufficient to destroy any bacteria which may be present upon it; the temperature produced is also wholly inadequate to sterilise any portions of clothing with which the bullet may come in contact, the latter, on the contrary, carrying with it into the wound those bacteria which may be present on the former.

WITH regard to the physiological action of oxygen in asphyxia, more especially in coal mines, a committee of the British Association has arrived at the following conclusions:(I) In the case of rabbits asphyxiated slowly or rapidly, oxygen is of no greater service than air, whether the recovery be brought about in an atmosphere contaminated by carbonic acid or compltiely free of carbonic acid, and whether artificial respiration be resorted to in addition or not. (2) Pure oxygen, when inhaled by a healthy man for five minutes, produces no appreciable effect on the respiratory rate and volume, nor on the pulse rate or volume. (3) Oxygen, whether pure or somewhat NO. I 253 , VOL. 49] diluted, produced no effect on one particular patient, who suffered from cardiac dyspnoa of moderately severe type, in the direction of ameliorating the dyspnœa, and, compared with air inhaled under the same conditions, produced no appreciable effect, either on the respiratory rate and volume or on the pulse rate and volume. (4) An animal may be placed in a chamber, the general cavity of which contains about 50 per cent. of carbonic acid, and retained there for a long time without supervention of muscular collapse, provided a gentle stream of a respirable air gas or oxygen, indifferently, be allowed to play upon the nostrils and agitate the surrounding atmosphere.

THE Quarterly Journal of the Geological Sociely (No. I96) has been issued.

Messrs. Dulau and Co. have issued a catalogue of works on Lepidoptera, Neuroptera, and Orthoptera.

Messrs. Whittaker and Co. have published a pamphlet, by Capt. M. P. Nadieine, on a new system of sanitary drainage and treatment of sewage matter.

The Matabele War has induced Mr. E. P. Mathers to issue a "Map of Mashonaland and Matabeleland." A few facts about the Matabeles and their country give the map additional interest.

WE have received a paper on "Rainmaking," read before the Texas Academy of Science in December I 892, in which Dr. A. Macfarlane discusses professional rain-makers (not the medicine men of the Indians, but their civilised prototypes) and disposes of their theories seriatim.

Though Mr. A. T. Burgess's "First Stage Agriculture" (Joseph Hughes and Co.) is adapted to the Elementary Syllabus of the Department of Science and Art, it should be valuable to all students of agriculture. The author is concise in his statements, so he has been able to give a large amount of information in a small book. A scarcity of illustrations is the book's only fault.

"THE Birds of Michigan," by Mr. A. J. Cook, are described in Bulletin No. 94 of the Michigan State Agricultural College. The bulletin is illustrated and contains a bibliography. In the text are recorded the food habits of the birds; so that the economic importance of the various species can be judged. A section is devoted to a statement of the laws that obtain in Michigan for the protection of game. The list is a useful con. tribution to the ornithology of an interesting region.

A USEFul book on the "Analysis of Milk and Milk Products," by Prof. Henry Leffmann and Dr. William Beam, has been published by Messrs. P. Blakiston, Son and Co., Philadelphia. The book appeals particularly to American agriculturists, but it may be introduced with profit into the dairy schools springing up in various parts of the country, and professional chemists will be interested in some of the analytical methods described.

Mr. HUgh Gordon's "Elementary Course of Practical Science," part 1, belonging to the series of Science Primers published by Messrs. Macmillan and Co., is worthy of introduction into all elementary and continuation schools. The experiments described are of a very simple nature, and refer to every-day phenomena. The pupil who conscientiously works through the little book will certainly have impressed upon him the im. portance of exactness, and will thus be given the best foundation of a scientific education.

ANOTHER book on practical physics is "Lessons and Exercises in Heat," by Mr. A. D. Hall (Rivington, Percival and Co.) The book contains a series of lessons and exercises, and is 
suitable for use as a supplement to lectures and demonstrations, The experiments described will impress the student with the fact that "science is measurement," hence they are of the right kind, for it is doubtful whether showy experiments are of any educational value. Schools and university classes requiring a good and accurate hancibook of heat for the physical laboratory would do well to adopt Mr. Hall's work.

Messrs. Longuans and Co. have just published, for Dr. F. Clemow, of the English Hospital, Cronstadt, "The Cholera Epidemic of 1892 in the Russian Empire." The author states in his preface that to the English medical world Russia is almost a closed book. The reason of this is that, in consequence of the difficulties of the Russian language, medical news from that courtry is rarely taken from the original source. Dr. Clemow, therefore, having a knowledge of Rusian, set himself to give a plain, unvarnished account of the epidemic of cholera which la it su nmar swept over tha Russian Empire, and to bring together information bearing upon the subject directly from the most authentic Russian sources. II seems to have spared no pains to get the statistics as full and trustworthy as possible, and was assured by the authorities that, notwithstanding the diff. culties atten ling their efforts to obtain proper returns from region; such a; Central Asia and Siberia, in no case did the error exceed ro per cent.

CARBIDE of silicon, $\mathrm{SiC}$, the beautifully crystalline sapphirelike substance whose preparation by M. Moissan with the aid of the electric furnace was described in our note of October 12, p. 572, forms the subject of a communication to the current publication of the Zeitschrift für Anorganische Chemie, by Dr. Muihlbäuser, of Chicago, whose preparation of the carbide of boron formed the subject of our last week's chemical note. It appears that Dr. Muihlhäuser had already completed a long and very elaborate research upon the preparation of this interesting compound upon a scale of considerable magnitude, for the ultimate purpose of its manufacture, before the communication of M. Moissan appeared. The mode by which it may be obtained in large quantities was perfected some time ago by Mr. Acheson, and Dr. Muiblhäuser now gives details of the process, together with considerable additions to our knowledge of its chemical and physical nature. The process essentially consists in heating a mixture of silica and carbon to the temperature of $3500^{\circ}$ by uneans of the electric furnace, when carbon monoxide escapes and silicon carbide is produced.

$$
\mathrm{SiO}_{2}+3 \mathrm{C}=\mathrm{SiC}+2 \mathrm{CO} \text {. }
$$

Silicate of alumina may be employed instead of silica with equally good results. The crystals obtained possess many of the properties, particulariy the hardness, of the diamond. According to the purity of the materials employed in their manufacture they are colourless, or coloured yellowish green, bluish green, or pale blue. The name carborundum is suggested for the substance. Upon the large scale the cheaper materials sand and coke are employed, with the addition of common salt as a fux. The latter acts mechanically, causing the unattacked portion of the ingredients to bake together, thus facilitating the separalion of the crystals; it also prevents loss of carbon by surface oxidation. One hundred parts of the powdered coke are mixed with one hundred parts of sand and twenty-five parts of salt. The mixture is placed in an electric furnace built of highly refractory fireclay. The electrodes are inserted through apertures at the ends of the furnace, and are connected with a central bar of carbon, the high resistance, round which the mixture is closely packed. The electrodes are in immediate connection with a powerful current transformer, which is connected in turn with an alternating current dynamo. The carbon high resistance bar is raised by the current to an intense white heat, which is in turn communicated to the mixture. Gas is rapidly evolved from the mass, and yeilow and blue flames dart out in all directions. As the heat increases the flame concentrates about one position until the fused salt rises to the surface, when an energetic action occurs, the gases eventually forcing their way through the liquid cru-t and heaping it up in the form of a crater, from which a high flame shoots up surrounded at its base by dense white clouds of vapour of salt, and eventually the remainder of the salt wells forth from the crater like veritable lava, carrying the dark impurities along with it. The interior of the crater, where the reaction is proceeding, is now seen to be white hot. The eruption soon commences to subside, the flames cease to appear, the outer crust hardens, and the reaction is complete.

THE product of this remarkable reaction is an ellipsoidal hardened mass, surrounding the carbon high resistance, and is found upon making a section to consist of six distinct layers. The first, close against the carbon bar, is a zone of graphite, which occurs in the form of hollowed hexagonal plates, pseudomorphs of silicon carbide, from which they are produced by dissociation at the extremely high temperature in the neighbourhood of the bar, silicon escaping as vapour. The second and by far the largest zone consists of the crystals of silicon carbide. They are largely found in elongated aggregates, radiating in all directions from the axis of the ellipsoid; the individuals forming the aggregates are bluish or yellowish-green, and of all sizes up to crystals a centimetre in diameter. Numerous isolated and highly perfect crystals of considerable size and great beauty are likewise found between the aggregates. Surrounding this zone of crystals is a narrow zone of amorphous carbide of silicon, outside which is found a layer of nodules of minerals produced from the impurities during the reaction; the fifth layer consists of the remains of uncombined mixture, and the sixth the crust of common salt. The crystais obtained by employing silicate of alumina are usually colourless or pale blue, and have been employed by M. Nikola Tesla in his new lamp for the transformation of electrical waves into waves of light. The powdered crystals explode violently when heated with potassium and lead chromates, but burn quietly with chromate of lead alone, forming dioxides of carbon and silicon. The powder exhibits a vivid greenish-yellow luminosity when heated in a platinum crucible. It is only very slightly attacked by the oxygen of the air under these circumstances, only 0.5 per cent. uniting in an hour. The fine powder, moreover, remains suspended in water for months without subsiding, although the specific gravity of the carbide at $15^{\circ}$ is $\mathbf{3} \mathbf{2 2}$.

THE additions to the Zoological Society's Gardens during the past week include a Macaque Monkey (Macacus cynomolgus, of from India, presented by Mr. Robert Gallon; a Chest. nut-eared Finch (Amadina castonotus) from Australia, a De Filippi's Meadow Starling (Sturnella deflippi) from South America, presented by Mrs. Kemp-Welch; two Laughing Kingfishers (Dacelo gisrantea) from Australia, presented by the Executors of the late Mr. Fred Burgess; a Punctured Salamander (Amblystoma punctatum) from North America, presented by Mr. J. H. Thomson, C.M.Z.S. ; four Common Toads (Bufo vulgaris) from Jersey, presented by Mr. J. Stanton; two White-handed Gibbons (Hyloiates lar. $\delta$ o), a - Bulbul (Hypsipetes —) from the Malay Peninsula, a Red and Yellow Macaw (Ara chloroptera) from South America, five Green Lizards (Lacerta viridis), three Black-spotted Toads (Bufo meianostictus), four Schlagintweit's Frogs (Rans cyano. phlyctis) from Ceylon, two Slow-worms (Anguis fragilis), three Fire-bellied Toads (Bombinator igneus) European, deposited; a Bar-tailed Godwit (Limosa lapponica), two Dunlins (Tringa alpina) British, purchased.

$$
\text { NJ. } 1253 \text {. VOL. 49] }
$$

